\title{
Violence against Women: Notifications of Health Professionals in Rio Grande do Sul
}

\author{
Priscila Lawrenz ${ }^{1, *}$, Davi Manzini Macedo ${ }^{2}$, Jean von Hohendorff ${ }^{3}$, \\ Clarissa Pinto Pizarro de Freitas ${ }^{4}$, Laura Nichele Foschiera ${ }^{1}$, \& Luísa Fernanda Habigzang ${ }^{1}$ \\ ${ }^{1}$ Pontifícia Universidade Católica do Rio Grande do Sul, Porto Alegre, RS, Brasil \\ ${ }^{2}$ Universidade Federal do Rio Grande do Sul, Porto Alegre, RS, Brasil \\ ${ }^{3}$ IMED, Passo Fundo, RS, Brasil \\ ${ }^{4}$ Universidade Salgado de Oliveira, Rio de Janeiro, RJ, Brasil
}

\begin{abstract}
The aim of this study was to characterize the situations of violence against women reported by health professionals in Rio Grande do Sul. A total of 20.999 reports were performed between 2010 and 2014. The most frequent reports included women aged 19 to 29 years old. The most frequent type of violence was physical, and the victim's residence was the most frequent place. Most of perpetrators were male, partner or ex-partner of the victim. Women were referred more frequently to clinics and police station. The results can support strategies for prevention and coping violence against women. The study allowed identifying weaknesses in the report information, as well as in the referrals made, indicating the need for investments in the training of health professionals.
\end{abstract}

KEYWORDS: gender violence, violence against women, domestic violence, public health

\section{Violência contra Mulher: Notificações dos Profissionais da Saúde no Rio Grande do Sul}

\begin{abstract}
RESUMO - Este estudo teve como objetivo caracterizar as situações de violência contra mulheres notificadas pelos profissionais da saúde no Rio Grande do Sul. Foram analisadas 20.999 notificações realizadas entre 2010 e 2014 . As notificações incluíram, com maior frequência, mulheres de 19 a 29 anos. A violência física foi a mais predominante, sendo a residência da vítima o principal local de ocorrência. A maioria dos agressores era do gênero masculino, parceiros ou ex-parceiros íntimos. As mulheres foram encaminhadas com maior frequência para ambulatórios e delegacias. Os resultados podem subsidiar estratégias para prevenção e enfrentamento da violência contra a mulher. O estudo permitiu identificar fragilidades nas informações notificadas, bem como nos encaminhamentos realizados, indicando a necessidade de investimentos na capacitação dos profissionais da saúde.
\end{abstract}

PALAVRAS-CHAVE: violência de gênero, violência contra a mulher, violência doméstica, saúde pública

Violence against women is defined as any act of gender violence that results, or has the possibility to result, in physical, sexual or psychological harm to women, including the threat of such acts, coercion or arbitrary deprivation of liberty in public or private environment (United Nations [UN], 1993). It is recognized as a violation of human rights and a serious public health problem (World Health Organization [WHO], 2016). This is a phenomenon that affects women in all parts of the world, and intimate partners are recognized as the main aggressors (Baugher \& Gazmararian, 2015; Miranda, Paula, \& Bordin, 2010; Schraiber et al., 2007).

Social and cultural factors should be considered when explored the nature of violence against women (Kronbauer $\&$ Meneghel, 2005; Saffioti, 2001). Therefore, it is necessary to understand gender as a constituent element of social

*E-mail: prisci_lawrenz@yahoo.com.br 
relations. 'Gender' is a cultural concept related to how society assigns different roles to men and women (Kronbauer $\&$ Meneghel, 2005). While men dominate and control, care and submission are expected of women. In many cultures, gender-based violence continues to be accepted as a normal practice and women silence their suffering (Kumar, Nizamie, \& Srivastava, 2013; White \& Satyen, 2015).

Estimates indicate that one in three women in the world will experience physical or sexual violence perpetrated by an intimate partner or sexual violence committed by another person during the course of life (WHO, 2016). In Brazil, the Women's Support Center (Central de Atendimento à Mulher - Ligue 180) is a free and confidential public service that receives notifications of violence, complaints about service network and guides women about legislation and their rights. According to Ligue 180 data, in 2015, 749.024 care were performed, an average of 62.418 per month and 2.052 per day. Of the total number of cares, $10.23 \%$ corresponded to reports on violence, which $58.86 \%$ was committed against black women. Among the reports, $50.16 \%$ corresponded to physical violence, $30.33 \%$ to psychological violence, $7.25 \%$ to moral violence, $4.54 \%$ to sexual violence and $2.10 \%$ to patrimonial violence. Most of the recorded cases of violence occurred in urban areas (90.14\%). In $72 \%$ of the cases, violence was committed by men who victims have or had some affective bond (e.g., ex-partners, spouses, boyfriends or lovers; Secretaria Especial de Políticas para as Mulheres, 2016).

Violence affects different aspects of women's lives, such as health, productivity and ability to care for themselves and their families (Kumar et al., 2013; Mendonça \& Ludermir, 2017). Physical aggressions with repeated or high intensity attacks can cause trauma (e.g., fractures and bleeding) and chronic injuries/diseases (e.g., chronic pain). The high levels of stress experienced by the victims may contribute to the development of hypertension, gastrointestinal problems and mental disorders (Miranda et al., 2010). Psychological symptoms can manifest in the form of denial, shock, confusion and fear. Disorders commonly presented by women victims of violence are depression, anxiety, Post-Traumatic Stress Disorder (PTSD), suicidal ideation, attempted suicide and substance abuse (Beydoun, Beydoun, Kaufman, \& Zonderman, 2012; Mendonça \& Ludermir, 2017; Miranda et al., 2010; Schraiber et al., 2007).

In 2006 entered into force a specific law that aims to prevent violence against women in Brazil, known as the "Maria da Penha Law". From this law, every case of violence against women becomes a crime and must go through police investigation. The law characterizes types of domestic violence as: (a) physical violence: any conduct that offends the integrity and body health; (b) psychological violence: conduct that causes emotional damage, decreased self-esteem, impairment of development and humiliation; (c) sexual violence: any conduct that constrain the woman to witness, maintain or participate in unwanted sexual intercourse, through intimidation, threat or use of force; prevention from using any contraceptive method or forced into marriage, pregnancy, abortion or prostitution; (d) patrimonial violence: retention, subtraction, partial or total destruction of its objects, working instruments, personal documents, goods, values or economic resources; (e) moral violence: any conduct that configures slander, defamation or injury (Lei Federal $n^{\circ} 11.340 .2006$ ).

From 2015 the Law Against Femicide entered into force. According to the new law, aggression committed against a female person in a family environment that intentionally cause injuries that lead to death are called femicide (Lei Federal $n^{\circ}$ 13.104, 2015). Between 2003 and 2013, the number of femicide victims increased from 3.937 to 4.762 , an increase of $21 \%$ in the decade. The 4.762 deaths in 2013 represent 13 daily femicides (Waiselfisz, 2015).

Since the 1970 s, notification of situations of violence is compulsory for all professionals and responsible for public and private health services (Lei Federal $n^{\circ} 6.259,1975$ ). The mandatory reporting of specific cases of violence against women attended in public or private health services was also established by Federal Law $n^{\circ} 10.788$, November 24th, 2003 (Lei Federal $n^{\circ} 10.788,2003$ ). Through the notification, protection agencies can act to break the cycle of violence and guarantee the victim protection. In addition, the notification allows mapping the characteristics of violence situation and their prevalence, which can be used in proposing prevention and coping policies (Gonçalves \& Ferreira, 2002).

Until recently, the description of the cases of violence that occurred in Brazil was limited to the information provided by the Mortality Information System (Sistemas de Informação sobre Mortalidade [SIM]), SUS Hospital Information System [Sistema de Informação Hospitalar do SUS SIH] and the analyzes of police reports. From 2009, notifications regarding interpersonal violence started to be performed through the SINAN Individual Notification Form (Ficha Individual de Notificação SINAN [FIN-SINAN]). FIN-SINAN is composed of questions about the characteristics of the victim, the place of occurrence and the typology of violence. In cases of sexual violence, the occurrence of penetration and the health procedures performed are investigated. Regarding the data of the probable aggressor perpetrator, the number of participants, the relationship/degree of kinship with the victim, gender and suspected alcohol use by the aggressor are questioned. Questions on the consequences of violence are also included, referrals in the health sector to the other services that compose the protection network and the evolution of the case (Ministério da Saúde, 2008).

This research fits into a project performed in partnership with the Rio Grande do Sul State Center for Health Surveillance (Centro Estadual de Vigilância em Saúde do Rio Grande do Sul [CEVS/RS]). This project aims to characterize the reports on violence against children, 
adolescents, adults and the elderly conducted by FIN-SINAN in the state. Posteriorly, it aims to use this data to train the professionals of the Regional Health Coordination of Rio Grande do Sul to identify, welcome, notify and refer cases of violence cared in their professional routine.

Aiming to contribute to the efforts of greater knowledge and dissemination of information on cases of violence against women, the aim of this study is to characterize the situations of violence perpetrated against this group notified through FIN-SINAN in the period between 2010 and the first semester of 2014. This study aims to identify the characteristics of the (a) victims (e.g., age, race and schooling); (b) situations of violence (e.g., types of violence, number of episodes and place of occurrence); and (c) aggressors (e.g., gender, relationship to the victim and suspicion of alcohol use). In addition, this study aims to investigate which referrals to the health and protection network were made after the notification.

\section{METHOD}

\section{Sample}

A total of 20.999 reports on violence against women performed in the period of 2010 to the first semester of 2014 in Rio Grande do Sul were analyzed.

\section{Procedures for Obtaining Data}

This study is part of a project performed in partnership with the Nucleus of Diseases and Noncommunicable Diseases of the State Center for Health Surveillance (Núcleo de Doenças e Agravos Não Transmissiveis do CEVS/RS) of Rio Grande do Sul. The CEVS/RS provided a database with 58.391 notifications of cases of violence involving children, adolescents, adults and the elderly conducted between $01 / 01 / 2010$ to $07 / 31 / 2014$. In this study, 20.999 reports on violence involving women aged 19-59 were included. The notifications that compose the database were performed by health professionals who work in hospitals, emergency services and Basic Health Units of the state, regarding cases of suspected or confirmed violence. The instrument for completing the data used by professionals is the FIN-SINAN, in its 2008 version. The information is based on a document authored by the Ministry of Health (2008).

The FIN-SINAN is initially filled in paper or in electronic form by health professionals. Subsequently, the forms should be sent to the services responsible for epidemiological surveillance of municipal secretariats, which weekly send the files in magnetic media to the State Health Secretariats. The research team did not control the conditions of collection of the variables that compose the listing and its export to virtual platform. These are internal procedures foreseen by the $C E V S / R S$ team that depend on the administrative organization of the state health services. For purposes of descriptive and inferential analysis, the research team exported the data to the software Statistical Package for the Social Sciences (SPSS version 21). The project was approved by Research Ethics Committee.

\section{Data Analysis}

The notifications were analyzed descriptively, aiming to characterize the profile of the victims, the situations of violence and the aggressors. In order to investigate whether there were differences in the frequency of reports on violence against women according to the sociodemographic characteristics of the victim (e.g., age group, schooling and marital status), Chi-Square $\left(\chi^{2}\right)$ analyzes were performed. In addition, $\chi^{2}$ analyzes were applied to assess whether the frequency of reports on violence against women presented significant differences. It was compared cases in which aggression was performed by one or more aggressors, according to the gender of the aggressor and whether the aggressor had ingested alcohol when committed the reported aggression.

\section{RESULTS}

Women were aged between 19 and 59 years old (M $=34.42$ years, $\mathrm{SD}=10.64)$ at the time of notification. A significant difference was observed in the age group of the victims. The results showed a greater number of reports among victims from 19 to 29 years old, while in the age group 50 to 59 fewer reports on violence were observed (see Table 1).
Regarding the race of women, $80.1 \%$ identified themselves as white. Regarding the educational level, 33.5\% reported incomplete elementary education. Reports on violence were more frequent among those who were literate and had incomplete elementary education. In all the reports analyzed, $49.9 \%$ of the women were married or were in a stable union. According to marital status, married women had the highest number of reports (see Table 1). 
Table 2 describes the types of violence, as well as the area and place of occurrence. Physical violence was the most frequent $(69.9 \%)$. In $50.3 \%$ of the situations there was use of corporal force or beating. The types of sexual violence included mostly rape. In the urban area, a greater number of cases $(88 \%)$ were identified, and the victim's residence was identified as the main place of occurrence $(76.4 \%)$.

In most situations of violence, the aggressions were committed by a single aggressor (82.1\%) and male (67.5\%). Partners or intimate ex-partners (e.g. spouses, ex-spouses,

Table 1. Personal and sociodemographic characteristics of women victims of violence

\begin{tabular}{|c|c|c|c|}
\hline Variable & $\mathbf{N}$ & $\%$ & $\chi^{2}$ \\
\hline Age & & & $3,554.09 *$ \\
\hline 19 to 29 & 7,801 & 38.6 & \\
\hline 30 to 39 & 6,049 & 29.9 & \\
\hline 40 to 49 & 4,118 & 20.4 & \\
\hline 50 to 59 & 2,237 & 11.1 & \\
\hline \multicolumn{4}{|l|}{ Race } \\
\hline White & 16,719 & 80.1 & \\
\hline Brown & 2,209 & 10.6 & \\
\hline Black & 1,201 & 5.8 & \\
\hline Indigenous & 93 & .4 & \\
\hline Yellow & 66 & .3 & \\
\hline Ignored & 582 & 2.8 & \\
\hline Education & & & $17,669.76^{*}$ \\
\hline $\begin{array}{l}\text { Incomplete Elementary } \\
\text { school }\end{array}$ & 6,543 & 33.5 & \\
\hline $\begin{array}{l}\text { Complete elementary } \\
\text { school }\end{array}$ & 3,129 & 16 & \\
\hline Complete high school & 3,115 & 15.9 & \\
\hline Incomplete high school & 1,467 & 7.5 & \\
\hline $\begin{array}{l}\text { Incomplete higher } \\
\text { education }\end{array}$ & 487 & 2.5 & \\
\hline Complete higher education & 584 & 3 & \\
\hline Illiterate & 257 & 1.3 & \\
\hline Ignored & 3,974 & 20.3 & \\
\hline Marital Status & & & $24,693.42 *$ \\
\hline Married/stable union & 9,691 & 49.9 & \\
\hline Single & 5,843 & 30.1 & \\
\hline Divorced & 2,221 & 11.4 & \\
\hline Widow & 346 & 1.8 & \\
\hline Ignored & 1,200 & 6.2 & \\
\hline Not applicable & 114 & .6 & \\
\hline
\end{tabular}

Note: $*-\mathrm{p} \leq .001$ boyfriends and ex-boyfriends) were responsible for $52.2 \%$ of reported cases of violence. In $39.8 \%$ of the cases, it was identified that the aggressor used alcohol. Significant differences in frequency of reporting were observed considering their characteristics (e.g., number of aggressors, gender of the aggressors and alcohol use) (see Table 3).

Table 2. Description of types of violence, area and place of occurrence

\begin{tabular}{|c|c|c|}
\hline Variable & $\mathbf{N}$ & $\%$ \\
\hline \multicolumn{3}{|l|}{ Types of violence } \\
\hline Physical violence & 6,109 & 69.9 \\
\hline Psychological violence & 3,386 & 47.1 \\
\hline Sexual violence & 1,101 & 5.6 \\
\hline Financial Violence & 481 & 2.5 \\
\hline \multicolumn{3}{|c|}{ Characteristics of physical violence } \\
\hline Use of body force or beating & 4,929 & 50.3 \\
\hline Sharpening object & 1,684 & 8.6 \\
\hline Hanging & 896 & 4.6 \\
\hline Blunt object & 851 & 4.4 \\
\hline Poisoning & 545 & 5.7 \\
\hline Fire gun & 479 & 2.5 \\
\hline Hot Substance & 167 & .9 \\
\hline \multicolumn{3}{|c|}{ Characteristics of sexual violence } \\
\hline Rape & 833 & 4.3 \\
\hline Sexual harassment & 213 & 1.1 \\
\hline Indecent exposure & 104 & 0.5 \\
\hline Sexual exploitation & 26 & .1 \\
\hline \multicolumn{3}{|l|}{ Occurrence of penetration } \\
\hline Vaginal penetration & 717 & 3.8 \\
\hline Anal penetration & 214 & 1.1 \\
\hline Oral penetration & 185 & .9 \\
\hline \multicolumn{3}{|l|}{ Area of occurrence of violence } \\
\hline Urban area & 16,950 & 88 \\
\hline Countryside & 1,852 & 9.6 \\
\hline Peri-urban zone & 342 & 1.8 \\
\hline Ignored & 111 & .6 \\
\hline \multicolumn{3}{|c|}{ Place of occurrence of violence } \\
\hline Residence & 15,592 & 76.4 \\
\hline Public highway & 2,502 & 12.3 \\
\hline Bar or similar & 410 & 2 \\
\hline Trade/services & 318 & 1.6 \\
\hline Others & 1,175 & 5.7 \\
\hline Ignored & 423 & 2.1 \\
\hline
\end{tabular}


Regarding the consequences of violence, in $19.9 \%$ of cases, PTSD was identified. Regarding the care, most of the women received outpatient care $(60.7 \%)$, and in $2.4 \%$, prophylaxis for HIV and other Sexually Transmitted Diseases (STDs). The police stations were the main points of referral of the protection network (31.9\%), followed by the Women's Police Stations (Delegacias Especializadas no Atendimento à Mulher - DEAM) (21.5\%). In $80.5 \%$ of the situations of violence, women were discharged (see Table 4).

Table 3. Number of aggressors per episode of violence, gender of the aggressor, relationship with the victim and alcohol use

\begin{tabular}{|c|c|c|c|}
\hline Variable & $\mathbf{N}$ & $\%$ & $\chi^{2}$ \\
\hline Number of aggressors & & & $22,376.78 *$ \\
\hline One aggressor & 16,784 & 82.1 & \\
\hline Two aggressors or more & 3,124 & 15.3 & \\
\hline Ignored & 533 & 2.6 & \\
\hline Gender of the aggressors & & & $22,563.30 *$ \\
\hline Male & 13,718 & 67.5 & \\
\hline Female & 5,366 & 26.4 & \\
\hline Both genders & 487 & 2.4 & \\
\hline Ignored & 744 & 3.7 & \\
\hline \multicolumn{4}{|l|}{ Aggressor } \\
\hline Spouse & 6,978 & 35.5 & \\
\hline Ex-spouse & 2,260 & 11.6 & \\
\hline Strange & 1,413 & 7.3 & \\
\hline Friend/Acquaintance & 1,343 & 6.9 & \\
\hline Son & 722 & 3.7 & \\
\hline Boyfriend & 666 & 3.4 & \\
\hline Brother & 493 & 2.6 & \\
\hline Ex-boyfriend & 423 & 2.2 & \\
\hline Mother & 258 & 1.3 & \\
\hline Father & 229 & 1.2 & \\
\hline $\begin{array}{l}\text { Alcohol use by the } \\
\text { aggressor }\end{array}$ & & & $516.17^{*}$ \\
\hline No & 8,068 & 39.8 & \\
\hline Yes & 6,758 & 33.4 & \\
\hline Ignored & 5,428 & 26.8 & \\
\hline
\end{tabular}

Note: $* \mathrm{p} \leq .001$.
Table 4. Consequences of violence, procedures and referrals to health services, referrals to the protection network and evolution of cases

\begin{tabular}{|c|c|c|}
\hline Variable & $\mathbf{N}$ & $\%$ \\
\hline \multicolumn{3}{|l|}{ Consequences of violence } \\
\hline Post-Traumatic Stress Disorder & 3,693 & 19.9 \\
\hline Suicide attempt & 1,511 & 8.2 \\
\hline Behavioral Disorders & 894 & 4.9 \\
\hline Mental Disorders & 465 & 2.5 \\
\hline Pregnancy & 65 & .4 \\
\hline STD contraction & 38 & .2 \\
\hline Other consequences & 677 & 3.8 \\
\hline \multicolumn{3}{|l|}{ Health referrals } \\
\hline Clinic & 11,994 & 60.7 \\
\hline Hospital & 2,512 & 12.7 \\
\hline Not applicable & 2,960 & 15 \\
\hline Ignored & 2,278 & 11.5 \\
\hline \multicolumn{3}{|l|}{ Health Procedures } \\
\hline Prophylaxis for HIV & 474 & 2.4 \\
\hline Prophylaxis for DST & 468 & 2.4 \\
\hline Blood collection & 411 & 2.1 \\
\hline Prophylaxis for Hepatitis B & 329 & 1.7 \\
\hline Emergency contraception & 283 & 1.5 \\
\hline Collection of vaginal secretion & 98 & 0.5 \\
\hline Collection of semen & 54 & 0.3 \\
\hline Abortion provided by law & 11 & 0.1 \\
\hline \multicolumn{3}{|l|}{ Referrals to network services } \\
\hline Other police stations & 6,145 & 31.9 \\
\hline Women's Police Stations & 4,120 & 21.5 \\
\hline Other referrals & 3,278 & 17.4 \\
\hline Women's Resource Center & 2,359 & 12.3 \\
\hline CRAS or CREAS & 1,941 & 10.2 \\
\hline National Legal Medicine Institute & 1,033 & 5.4 \\
\hline Public Ministry & 733 & 3.9 \\
\hline Guardianship council & 636 & 3.4 \\
\hline Shelter House & 252 & 1.3 \\
\hline Child and Adolescent Protection Center & 96 & .5 \\
\hline Sentinela program & 48 & .3 \\
\hline Juvenile court & 45 & .2 \\
\hline \multicolumn{3}{|l|}{ Evolution of cases } \\
\hline High & 15,704 & 80.5 \\
\hline Death due to violence & 429 & 2.2 \\
\hline Escape/evasion & 273 & 1.4 \\
\hline Death due to other causes & 21 & .1 \\
\hline Ignored & 3,072 & 15.8 \\
\hline
\end{tabular}




\section{DISCUSSION}

This study aimed to characterize the situations of violence against women reported by health professionals through the SINAN Individual Notification Form (FINSINAN) in Rio Grande do Sul. The analyzes have identified the severity of aggressions suffered by women in the state and the importance of notification by health professionals who care the cases. The investigation of situations of violence is important since it contributes to decrease the invisibility of this reality experienced by countless women in Brazil. Although considered a public health problem, confront this type of violence demand more effective action and include different sectors of society (Delziovo, Bolsoni, Nazário, \& Coelho, 2017).

Regarding the characteristics of the victims, the number of reports on violence differed according to age group of women. This result agrees with previous studies that identified that the highest incidence of aggressions against women occurs in the age groups between 18 and 29 years old (Deslandes, Gomes, \& Silva, 2000; Saffioti, 1997). The data can also be interpreted from the assumption that women with more advanced ages report less the situations of violence experienced. For a long time, the importance of being a good wife and mother was strongly linked to values that made women more vulnerable to violence. Even today, many victims do not report aggressions due to fear, shame, family pressures and difficulty in understanding such acts as a crime (Kumar et al., 2013). This also occurs due to the institutional inefficiency that includes the negative attitudes of the justice system, bureaucracy, lack of orientation and revictimization (Meneghel et al., 2011).

Most reports made by health professionals included white women. This result, which differs from the data released from Ligue 180 (Secretaria Especial de Políticas para as Mulheres, 2016) may be related to the demographic profile of Rio Grande do Sul. In the last population census, $83.22 \%$ of the population was declared white (Instituto Brasileiro de Geografia e Estatística [IBGE], 2010).

Reports on violence were more frequent among women with incomplete elementary school. This data agrees with a study that aimed to verify the prevalence and the types of violence committed against 251 women who consulted a Basic Health Unit of Porto Alegre (RS). Women with fewer years of schooling presented higher prevalence of violence (Kronbauer \& Meneghel, 2005). In addition to the educational level, these results may also reflect differences in socioeconomic and related to the health service accessed. Women with higher schooling and purchasing power tend to search for health services and may request that the situation of violence will not be notified (Oliveira, Cardoso, Almeida, Cardoso, \& Gutfilen, 2014), despite the obligation for all health services in the country. Even though it was identified a higher frequency of notifications involving young women, white, with incomplete elementary school, who were married or were in a stable union, it should be noticed that violence is a democratic phenomenon that can affect women regardless of their personal and social characteristics (Meneghel et al., 2011; Saffioti, 2001).

Among the type of violence, the most frequent was physics. However, as identified in other studies, violence against women may involve multiple aggressions. In many cases, physical violence is followed by psychological and sexual abuse (Deslandes et al., 2000; Fonseca, Ribeiro, \& Leal, 2012; Kronbauer \& Meneghel, 2005). The results found in this study differed from that observed by Schreiber et al. (2007), in which psychological violence was identified as more frequent. This difference may be related to the fact that, in general, health services are accessed when violence leaves physical marks. In addition, many women and even health professionals have difficulty to identifying situations of psychological violence. Similarly, many women are forced to have sex with their partners and do not identify such situations as violence (White \& Satyen, 2015).

The highest number of reported violence occurred in urban areas and in the residence of the victim. The domestic context has been identified in the literature as the main place of occurrence of violence against women (Bruschi, Paula, \& Bordin, 2006; Deslandes et al., 2000; D'Oliveira et al., 2009; Schraiber et al., 2007; Silva, Lima, \& Ludermir, 2017; White \& Satyen, 2015; WHO, 2016). The privacy of home often hides the abuses committed (Deslandes et al., 2000). Individuals with whom women have or had intimacy and affective bonds, such as spouses and ex-spouses, are identified as the main aggressors (Baugher \& Gazmararian, 2015; Gallagher \& Parrott, 2011; Miranda et al., 2010; Schraiber et al., 2007; White \& Satyen, 2015; WHO, 2016). Beliefs about the social roles that must be played by men include violence and the devaluation of what is considered feminine (Baugher \& Gazmararian, 2015; Gallagher \& Parrott, 2011). Men who manifest defensive feelings and insecurity in their relationships may use violence as a way to regain a sense of power and control (Baugher \& Gazmararian, 2015; Gallagher \& Parrott, 2011; Reidy, Berke, Gentile, \& Zeichner, 2014). It is essential that interventions for violence prevention are based on the deconstruction of gender stereotypes that contribute to unequal power relations between men and women. In addition, it is important to consider the frequency of cases in which the perpetrator used alcohol. This is a risk factor that should also be considered in violence prevention policies. 
Regarding the consequences of violence attributed by health professionals, PTSD was more frequently identified. This data should be interpreted with caution since the diagnosis of PTSD requires a minimum period of one month of maintenance of the symptoms after the traumatic episode (American Psychiatric Association [APA], 2013). Thus, this may make it impossible to identify the disorder at the time of the service that generated the notification of violence. In order to complete the field related to the consequences, a clinical diagnosis issued by a qualified professional is required (Ministério da Saúde, 2008). Difficulties in identifying the consequences have produced a considerable amount of missing information in the database. In the version of FIN-SINAN which entered into force in 2015, the consequences fields were excluded (Ministério da Saúde, 2015b).

Regarding health care received by women victims of violence, most were attending in clinics and discharged after the completion of health procedures. It should be noted that, despite the high frequency of cases of sexual violence that included rape, prophylaxis for HIV and other STIs were performed in only $2.4 \%$. This result may indicate the lack of knowledge or training of professionals on referrals recommended by the Ministry of Health (2015a) for cases of sexual violence. In addition, the practice of some health professionals may be permeated by cultural values that minimize the seriousness of sexual violence against women.
Due to the serious repercussions, the victim of sexual violence requires a service that promotes the reduction of injuries and damages to health. For this purpose, should be included measures to protect pregnancy and contamination by STIs (Faúndes, Rosas, Bedone, \& Orozco, 2006).

Regarding the referrals to the safety net, women were more frequently referred to police stations. This result may be related to the fact that most of the cities of Rio Grande do Sul do not have Women's Police Stations or Women's Assistance (DEAMs). The DEAMs are specialized units of the Civil Police that performs actions of prevention, protection and investigation crimes of domestic and sexual violence against women. In this place, police reports, request to the judge of protective measures and investigation of the crimes are performed (Secretaria de Políticas para as Mulheres da Presidência da República, 2016). In addition to the police stations, it was identified that many cases were referred to other services (e.g., Women's Resource Center, Guardianship Council, etc). The diversity of referrals may represent a lack of organization between the health network and protection since police stations should be the gateway to cases of violence against women. According to Meneghel et al. (2011), who evaluated the journey in Porto Alegre (RS) by women search for breaking the violence, it was not possible to identify a precise and efficient flow between services, and the way is different for each woman.

\section{CONCLUSIONS}

This study made it possible to understand the characteristics of situations of violence against women reported in Rio Grande do Sul by health professionals. The main limitations of this study included the lack of control over the data collection and the export to the virtual platform of the variables that compose FIN-SINAN 2008. In addition, the analysis of the data indicated the presence of a large number of information that was reported as "ignored" by health professionals or that appeared as "absent" in the database. The absence of such information may be related to the complexity involved in the dynamics of violence and the reluctance of some victims and health professionals to report on all aspects involved in the situation. On the other hand, it can also represent the care of the professionals respondents with the information since it may not have been identified. In any case, health professionals should receive training in order to sensitize the importance of reporting and complete filling of the data. In any case, health professionals should be trained to sensitize them about the importance of reporting and completing accurate and complete data.
Violence against women is not a recent phenomenon. What is recent is the concern with confrontation, criminalization and the understanding that it is a public health problem. Abuses occur in relational and social levels, which requires cultural and educational changes for their confrontation that go beyond the criminalization of aggressors. Understanding the characteristics of aggressions and the dynamics of violence against women provide the appropriate assistance of victims and planning prevention strategies. It is increasingly important that health professionals understand the importance of reporting and making appropriate referrals for each case. The main contribution of this study is to provide subsidies that may assist in the qualification of the policy of epidemiological surveillance and the care of women victims of violence. Assessing the strengths and weaknesses of these initiatives can contribute to the more effective use of public resources to coping violence against women. 


\section{REFERENCES}

American Psychatric Association. (2013). Manual Diagnóstico e Estatístico de Transtornos Mentais - $5^{a}$ edição. Porto Alegre: Artmed.

Baugher, A., \& Gazmararian, J. A. (2015). Masculine gender role stress and violence: A literature review and future directions. Aggression and Violent Behavior, 24, 107-112. doi: 10.1016/j. avb.2015.04.002

Beydoun, H. A., Beydoun, M. A., Kaufman, J. S., \& Zonderman, A. B. (2012). Intimate partner violence against adult women and its association with major depressive disorder, depressive symptoms and postpartum depression: A systematic review and meta-analysis. Social Science \& Medicine, 75(6), 959-975. doi: 10.1016/j.socscimed.2012.04.025.

Bruschi, A., Paula, C. S., \& Bordin, I. A. S. (2006). Prevalência e procura de ajuda na violência conjugal física ao longo da vida. Revista de Saúde Pública, 40(2), 256-264. Retrieved from http://www.redalyc.org/pdf/672/67240152011.pdf

Delziovo, C. R., Bolsoni, C. C., Nazário, N. O., \& Coelho, E. B. S. (2017). Características dos casos de violência sexual contra mulheres adolescentes e adultas notificados pelos serviços públicos de saúde de Santa Catarina, Brasil. Cadernos de Saúde Pública, 33(6), 1-13. doi: 10.1590/0102-311x00002716

Deslandes, S. F., Gomes, R., \& Silva, C. M. F. P. (2000). Caracterização dos casos de violência doméstica contra a mulher atendidos em hospitais públicos do Rio de Janeiro. Cadernos de Saúde Pública, 16(1), 192-137. Retrieved from http://www.scielo.br/pdf/\%0D/csp/v16n1/1571.pdf

D’Oliveira, A. F. P. L., Schraiber, L. B., França-Junior, I., Ludermir, A. B., Portella, A. P., Diniz, C. S., ... Valença, O. (2009). Fatores associados à violência por parceiro íntimo em mulheres brasileiras. Revista de Saúde Pública, 43(2), 299-310. Retrieved from http://www.scielo.br/pdf/rsp/v43n2/7172.pdf

Faúndes, A, Rosas, C. F., Bedone, A. J., \& Orozco, L. T. (2006). Violência sexual: Procedimentos indicados e seus resultados no atendimento de urgência de mulheres vítimas de estupro. Revista Brasileira de Ginecologia e Obstetrícia, 28, 126-135. doi: 10.1590/S0100-72032006000200009

Fonseca, D. H., Ribeiro, C. G., \& Leal, N. S. B. (2012). Violência doméstica contra a mulher: Realidades e representações sociais. Psicologia \& Sociedade, 24(2), 307-314. doi: 10.1590/S010271822012000200008

Gallagher, K. E., \& Parrott, D. J. (2011). What accounts for men's hostile attitudes toward women? The influence of hegemonic male role norms and masculine gender role stress. Violence Against Women, 17(5), 568-583. doi: 10.1177/1077801211407296

Gonçalves, H. B., \& Ferreira, A. L. (2002). Notificação da violência intrafamiliar contra crianças e adolescentes por profissionais da saúde. Cadernos de Saúde Pública, 18(1), 315-319. doi: 10.1590/S0102-311X2002000100032

Instituto Brasileiro de Geografia e Estatística. (2010). Censo 2010. Retrieved from http://censo2010.ibge.gov.br/

Kronbauer, J. F. D., \& Meneghel, S. N. (2005). Perfil da violência de gênero perpetrada por companheiro. Revista de Saúde Pública, 39(5), 695-701. Retrieved from http://www.redalyc. $\mathrm{org} / \mathrm{pdf} / 672 / 67240149001 . \mathrm{pdf}$

Kumar, A., Nizamie, S. H., \& Srivastava, N. K. (2013). Violence against women and mental health. Mental Health and Prevention, 1, 4-10. doi: 10.1016/j.mhp.2013.06.002

Lei $\mathrm{n}^{\circ} 6.259$, de 30 de outubro de 1975 (1975, 31 de outubro). Dispõe sobre a organização das ações de Vigilância Epidemiológica, sobre o Programa Nacional de Imunizações, estabelece normas relativas à notificação compulsória de doenças, e dá outras providências. Diário Oficial da União, seção 1.

Lei $n^{\circ} 10.788$, de 24 de novembro de 2003 (2003, 24 de novembro). Dispõe sobre a notificação compulsória, no território nacional, do caso de violência contra a mulher que for atendida em serviços de saúde públicos ou privados. Diário Oficial da União, livro 1.

Lei Federal no 11.340, 07 de agosto de 2006 (2006, 07 de agosto). Dispõe sobre os mecanismos para coibir a violência doméstica e familiar contra a mulher. Diário Oficial da União, livro 1.

Lei Federal no 13.104, 09 de março de 2015 (2015, 09 de março). Dispõe sobre a alteração do art. 121 do Decreto-Lei no 2.848 , de 7 de dezembro de 1940 - Código Penal, para prever o feminicídio como circunstância qualificadora do crime de homicídio, e o art. 1ํ da Lei no 8.072 , de 25 de julho de 1990, para incluir o feminicídio no rol dos crimes hediondos. Diário Oficial da União, livro 1.

Mendonça, M. F. S., \& Ludermir, A. B. (2017). Intimate partner violence and incidence of common mental disorders. Revista de Saúde Pública, 51(32), 1-8. doi: 10.1590/s15188787.2017051006912

Meneghel, S. N., Bairros, F., Mueller, B., Monteiro, D., Oliveira, L. P., \& Collaziol, M. E. (2011). Rotas críticas de mulheres em situação de violência: Depoimentos de mulheres e operadores em Porto Alegre, Rio Grande do Sul, Brasil. Cadernos de Saúde Pública, 27(4), 743-752. doi: 10.1590/ S0102-311X2011000400013.

Ministério da Saúde. (2008). Sistema de Informação de Agravos de Notificação - Ficha de Notificação Individual Violência Interpessoal e Autoprovocada. Retrieved from http://www.saude.rs.gov.br/upload/1339685891 Ficha\%20de $\% 20$ notifica $\%$ C3\%A7\%C3\%A3o\%20de\%20 viol\%C3\%AAncia\%20-\%20SINAN.pdf

Ministério da Saúde. (2015a). Norma técnica: Atenção humanizada às pessoas em situação de violência sexual com registro de informações e coleta de vestígios. Retrieved from http://www.spm.gov.br/central-de-conteudos/publicacoes/ publicacoes/2015/ norma-tecnica-versaoweb.pdf

Ministério da Saúde. (2015b). Sistema de Informação de Agravos de Notificação - Ficha de Notificação Individual Violência Interpessoal/Autoprovocada. Disponível em http://www.saude. pr.gov.br/arquivos/File/Ficha_Viol_5_1_Final_15_06_15.pdf Miranda, M. P. M., Paula, C. S., \& Bordin, I. A. (2010). Violência conjugal física contra a mulher na vida: Prevalência e impacto imediato na saúde, trabalho e família. Revista Panamericana de Salud Pública, 27(4), 300-308. doi: 10.1590/S102049892010000400009

Oliveira, F., Cardoso, K. R. L., Almeida, C. A. P., Cardoso, L. R., \& Gutfilen, B. (2014). Violence against women: Profile of the aggressors and victims and characterization of the injuries. A forensic study. Journal of Forensic and Legal Medicine, 23, 49-54. doi: 10.1016/j.jflm.2014.01.011

Reidy, D. E., Berke, D. S., Gentile, B., \& Zeichner, A. (2014). Man enough? Masculine discrepancy stress and intimate partner violence. Personality and Individual Differences, 68, 160-164. doi: 10.1016/j.paid.2014.04.021

Saffioti, H. I. B. (2001). Contribuições feministas para o estudo da violência de gênero. Cadernos Pagu, 16, 115-136. doi: $10.1590 /$ S0104-83332001000100007 
Saffioti, H. I. B. (1997). No fio da navalha: Violência contra crianças e adolescentes no Brasil atual. In F. R. Madeira (Org.), Quem mandou nascer mulher? Estudos sobre crianças e adolescentes pobres no Brasil (pp. 135-121). Rio de Janeiro: Editora Record/ Rosa dos Tempos.

Schraiber, L. B., D’Oliveira, A. F. P. L., França-Júnior, I., Diniz, S., Portella, A. P., Ludermir, A. B., ... Couto, M. T. (2007). Prevalência da violência contra a mulher por parceiro íntimo em regiões do Brasil. Revista de Saúde Pública, 41(5), 797-807. doi: 10.1590/S0034-89102007000500014 Secretaria de Políticas para as Mulheres da Presidência da República. (2016). O que é delegacia especializada no atendimento à mulher (DEAM)? Retrieved from http://www. spm.gov.br/arquivos-diversos/acesso-a-informacao/perguntasfrequentes/violencia/o-que-e-delegacia-especializada-noatendimento-a-mulher-deam

Secretaria Especial de Políticas para as Mulheres. (2016). Balanço 2015 - Ligue 180. Retrieved from http://www.spm.gov.br/ noticias/ligue-180-registrou-749-024-atendimentos-em-2015

Secretaria Especial de Políticas para as Mulheres. (2011). Politica Nacional de Enfrentamento à Violência contra as Mulheres. Retrieved from http://www.compromissoeatitude.org.br/wpcontent/uploads/2012/08/Politica-Nacional.pdf
Silva, J. M. M., Lima, M. C., \& Ludermir, A. B. (2017). Intimate partner violence and maternal educational practice. Revista de Saúde Pública, 51(34), 1-11. doi: 10.1590/s15188787.2017051006848

United Nations. (1993). Declaration on the Elimination of Violence against Women. Retrieved from https://documents-dds-ny. un.org/doc/UNDOC/GEN/N94/095/05 /PDF/N9409505. pdf?OpenElement

Waiselfisz, J. J. (2015). Mapa da Violência 2015: Homicídio de mulheres no Brasil. Retrieved from http://www. mapadaviolencia.org.br/

White, M. E., \& Satyen, L. (2015). Cross-cultural differences in intimate partner violence and depression: A systematic review. Aggression and Violent Behavior, 24, 120-130. doi: 10.1016/j. avb.2015.05.005

World Health Organization. (2016). Violence against women. Retrieved from http://www.who.int/mediacentre/factsheets/ fs $239 / \mathrm{en} /$
Submitted: $23 / 08 / 2016$

Reviewed: 09/08/2017

Accepted: 03/10/2017 